\title{
Composition Analysis of the Colostrum and Attempted Hand-rearing of a Neglected Harbor Porpoise (Phocoena phocoena)
}

\author{
Marin MATSUSHIRO ${ }^{1)}$, Masatoshi TSUNOKAWA ${ }^{2)}$, Takashi MATSUISHI ${ }^{3)}$ and Takanori KOORIYAMA ${ }^{1 \text { * }}$ \\ 1) Laboratory of Companion Animal Behavior and Wildlife Ecology, Department of Veterinary Science, \\ School of Veterinary Medicine, Rakuno Gakuen University, 582, Bunkyodai-Midori, Ebetsu, Hokkaido, 069-8501, Japan \\ 2) Otaru Aquarium, 3-303 Shukutsu, Otaru, Hokkaido, 047-0047, Japan \\ 3) Faculty of Fisheries Sciences, Hokkaido University, 3-1-1, Minato, Hakodate, Hokkaido, 041-8611, Japan
}

[Received 1 August 2019; accepted 2 April 2020]

\begin{abstract}
The harbor porpoise is a marine mammal rarely seen in aquariums. The ecology of this species is not well known, and captive breeding is difficult without essential information such as milk composition, amount consumed and frequency nursed per day, and lactation period. At the Otaru Aquarium in Japan, several deliveries of harbor porpoise offspring have occurred, but the calves have not survived. In the present study, we analyzed the colostrum of a harbor porpoise and attempted to hand-rear a calf using artificial milk after the mother denied nursing. The crude fat and crude protein contents of the colostrum were relatively high compared to values for other odontocetes. The present information will be helpful for future efforts to hand-rear harbor porpoises.
\end{abstract}

Key words: colostrum, hand-rearing, harbor porpoise

— Jpn J Zoo Wildl Med 25(2) : 81-89, 2020

Over 30 species of cetaceans inhabit around Japan, and most aquarium dolphins are from the wild. However, in 2015, the World Association of Zoo Aquariums (WAZA) advocated that animals in zoos and aquariums should be born and bred in captivity rather than be introduced from the wild. The Japanese Association of Zoos and Aquariums (JAZA) also decided against capturing dolphins by drive hunting after consulting with WAZA [1]. Therefore, artificial breeding techniques must be developed for dolphins to continue being exhibited in Japan.

Captive dolphin breeding is challenging; stillbirths, spontaneous abortions, and inappropriate maternal behavior are common. In one US aquarium, out of 74 common bottlenose dolphin (Tursiops truncatus) pregnancies, there were 60 viable births, 7 stillbirths, and 7 spontaneous abortions [2]. Furthermore, if the mothers show inappropriate maternal behavior, hand-rearing will be required for calves. There have been few attempts to hand-rear for neglected dolphin in Japan. In 2018, a pacific white-sided dolphin

* Corresponding author : Takanori KOORIYAMA

(E-mail: kooriyam@rakuno.ac.jp)
(Lagenorhynchus obliquidens) calf gave birth in Japanese aquarium. Because the mother did not show any maternal behavior, the keeper tried to hand-rear with artificial milk, but the calf died five days after birth [3]. So far only one successful case has been reported in Japan. At the Toba Aquarium in Mie, Japan, keepers successfully hand-reared a narrow-ridged finless porpoise (Neophocaena asiaeorientalis) for the first time in Japan [4]. In this case, the mother began to suckle the calf but suddenly refused 4 days after birth. For this reason, the keeper decided to separate the two and switch to hand-rearing using artificial milk, allowing the calf to wean completely. However, the previous eight cases of hand-rearing at Toba Aquarium were not successful, and were as short as 1-8 days.

Recently, it has been reported that the causes of mortality in common bottlenose dolphins differ with age [5]. It is thought that mortality varies among periods according to the critical developmental processes that occur therein. Death at 0-1 days after birth occurred primarily due to trauma and failure to thrive. At 2-7 days after birth, the majority of deaths were due to failure to thrive. At 8-30 days after birth, the majority of deaths resulted from infection, poor physical condition, 
and a poorly developed immune system. To ensure successful hand-rearing, it is important to provide sufficient nutrition to promote a healthy weight and proper immune function.

The harbor porpoise (Phocoena phocoena) is a small cetacean that is widely distributed in coastal areas of the Northern Hemisphere [6]. They have a short lactation period (8-12 months) compared to other delphinids (typically 12-20 months) [7, 8]. There are a few examples of breeding harbor porpoises in captivity [9, 10]. The Otaru Aquarium in Japan provides the only example of rearing and breeding small herds [11]. Two births have occurred at the Otaru Aquarium. In the first case, the mother had a miscarriage. In the second case, the calf died soon after birth as a result of liver damage caused by compression of the birth canal [12]. Protocols for hand-rearing have already been established for bottlenose dolphins [13]. On the other hand, due to the small number of successful cases, protocols for hand-rearing harbor porpoises have not yet been established.

Milk is the only source of nutrition for calves, whose growth is strongly tied to milk composition. Moreover, milk plays an important role for newborn animals in terms of immunity. Ungulates produce colostrum that is rich in proteins, which contribute to the formation of enzymes and antibodies [14]. The protein composition of colostrum differs widely across species. However, reliable information on the milk composition of dolphins and whales is surprisingly scarce, particularly with regard to colostrum $[7,15]$. Little information for milk composition exists for closely related species of the harbor porpoise. As for narrow-ridged finless porpoise species, their milk composition has been analyzed at 8 days after birth [4] and at different lactation stages in porpoises that are distributed in freshwater and in seawater [16]. In the beluga (Delphinapterus leucas), the basic milk components have been analyzed for milk collected $6 \mathrm{hr}$ after the death of the mother [17]. The only available data for the basic milk components of the harbor porpoise date back 130 years [18]. Furthermore, lactation periods were not reported in the aforementioned studies of the beluga or of harbor porpoises. According to staff members of aquariums, only one artificial milk product has been developed in Japan for marine mammals (Snow Brand Milk Products Company, td., Tokyo, Japan), and it the only commercially available product for various types of animals. Moreover, this product is not currently manufactured and is difficult to obtain. Thus, if the composition of natural milk

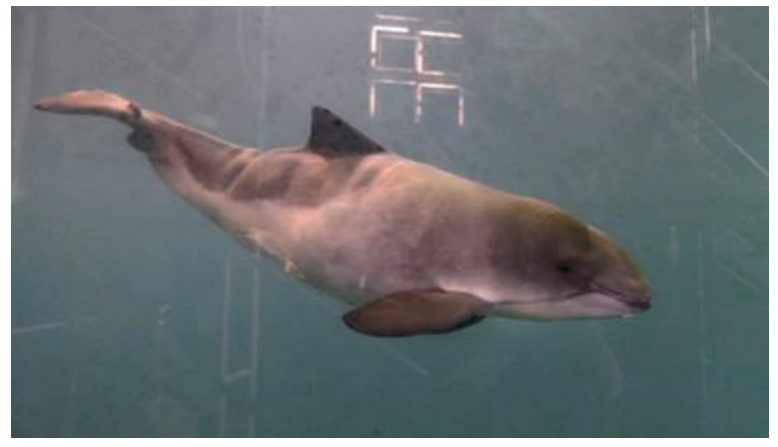

Fig. 1 The focal calf 2 days after birth.

can be determined, artificial milk with a more appropriate composition can be produced for calves.

In the present study, we analyzed a rare sample of colostrum of a harbor porpoise mother from the Otaru Aquarium in Hokkaido, Japan. We determined the characteristics of harbor porpoise milk by comparing its composition with those of milk from other odontocetes. We also suggest improvements for marine mammal-specific artificial milk.

A milk sample (colostrum) was obtained from a female harbor porpoise (estimated age of 14 years) kept at the Otaru Aquarium. The mother gave birth on May 30, 2017. The calf was female, and weighed $9.7 \mathrm{~kg}$ and measured $78.5 \mathrm{~cm}$ long 2 days after birth (Fig. 1). Immediately after giving birth, the mother was looking at the calf from behind. The calf was sometimes caught in the net installed in the pool to prevent collision with the wall, and was repeatedly rescued by divers. After observing this, the mother seemed to lose interest in the calf; she did not swim alongside it or assume a suckling position. The first nursing attempt in captive harbor porpoises is usually made within $2 \mathrm{hr}$ after birth, and successful nursing tends to occur within $4 \mathrm{hr}$ after birth, although these behaviors often vary markedly among individuals [9]. However, in this case, the keepers decided to separate the mother and calf at $2 \mathrm{hr}$ after birth, before the aquarium opened to the public, because the mother had lost interest in the calf and the staff would be occupied during opening hours. The mother dolphin was driven into the net and restrained by several keepers without sedation. The pool for the calf was approximately $15 \times 36 \mathrm{~m}$ and had an average depth of $3.5 \mathrm{~m}$. The water temperature during the hand-rearing period was maintained at $16.4 \pm 1.1^{\circ} \mathrm{C}$ (mean $\pm \mathrm{SD}$ ). While the mother was restrained to remain separate from her calf, the keepers collected milk 
from the mother's nipple using a specialized tool and obtained $8 \mathrm{~g}$ of colostrum. The tool was designed and modified by the keepers at the Otaru Aquarium to collect milk for bottle-feeding orphans and was constructed from a modified intravenous infusion chamber and 100-ml syringes [19]. The keepers planned to give the colostrum to the calf, but too little was available to feed her. The keepers believed that, to promote hand-rearing success, it would be preferable to determine the milk components at this stage than to give only a small amount of colostrum to the calf. Therefore, the sample was instead used for analysis. Because the mother had not received husbandry training, no further sampling was conducted, as capturing her again would have been overly stressful. The calf was observed and hand-reared by three people on a 24 -hr basis. Immediately after the separation, the calf nearly collided with the wall of the hand-rearing pool. Therefore, the keepers stationed themselves along the wall to prevent the calf from colliding with the wall. The calf appeared to become sufficiently familiar with the shape of the pool to largely avoid colliding with its wall in the afternoon. For 13 days after birth, the keepers observed the calf' s behaviors, including sleep, during which the calf floated on the surface of the water and stopped moving for up to 75 min. It is unknown whether this is a normal behavior or unique to the harbor porpoise calf.

During hand-rearing, the calf was held at the water surface and a feeding tube was inserted into the stomach by three keepers (Fig. 2). The feeding tube was placed $40 \mathrm{~cm}$ from the rostrum, and after checking for backflow of gastric juice, the keepers injected artificial milk into its stomach. Beginning 10 days after birth, a transparent feeding tube was used to help determine the presence or absence of gastric-juice backflow and the remaining amount of artificial milk. The keepers performed the artificial-milk feeding at 90-min intervals (16 times/day), and the growth of the calf was monitored by measuring its weight. The composition and amount of the artificial milk were adjusted based on calf weight. Because so few studies have reported the milk components of the harbor porpoise, the keepers decided to refer to the recipe of the artificial milk previously used by the Toba Aquarium to successfully hand-rear a narrow-ridged finless porpoise [4]. This artificial milk recipe was a mixture of Esbilac for dogs (Kyoritsu Seiyaku Corporation, Tokyo, Japan), fresh cream (Snow Brand Milk Products Company, td., Tokyo, Japan), salmon oil (FISH4DOGS, Worcestershire, UK), and several

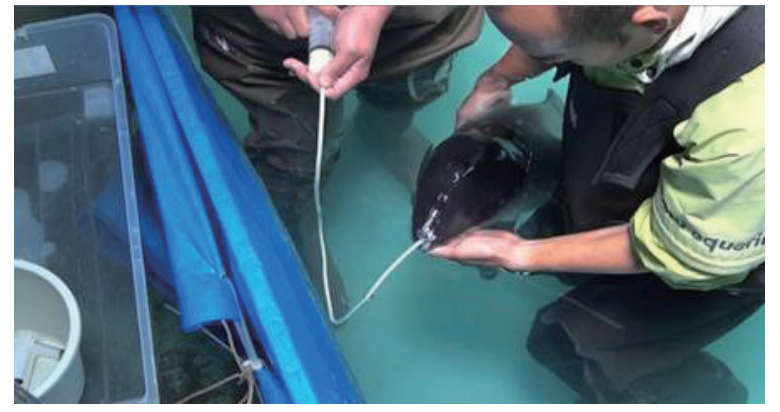

Fig. 2 The focal calf being tube-fed in the water by keepers.

supplements. Table 1 presents a 14-day regimen of the artificial milk. The artificial milk was warmed to $36^{\circ} \mathrm{C}$.

The collected colostrum sample was preserved at $-30{ }^{\circ} \mathrm{C}$ until analysis. The main components of the milk (i.e., water, crude fat, crude protein, and crude ash) were analyzed. The methods are outlined in Table 2 [20]. The milk sample was analyzed at the Japan Food Research Laboratories, Chitose Laboratory, Hokkaido, Japan. The results were compared to the milk composition of six other species of odontocetes [4, 7, 16-18], the milk mixture outlined in the present study, and the commercially available artificial milk developed for marine mammals (Snow Brand Milk Products Company, td., Tokyo, Japan). We then used this information to attempt to formulate an improved artificial milk.

We were able to successfully collect and analyze the harbor porpoise colostrum. Unfortunately, despite the keepers' efforts, the calf died at 14 days after birth. During hand-rearing, the keepers monitored the condition and growth of the calf 24 hr a day and changed the composition and amount of milk accordingly. However, the calf' s weight increased very little throughout the hand-rearing period, ranging from $9.46 \mathrm{~kg}$ to $9.70 \mathrm{~kg}$. Changes in body weight and caloric intake indicated that the artificial milk did not contain enough nutrients for the calf (Fig. 3). At 13 days after birth, the frequency of milkywhite, cream-like floating stools increased significantly, and vomiting was observed, suggesting indigestion. The keepers responded by decreasing the amount of salmon oil from $5 \mathrm{ml}$ to $2 \mathrm{ml}$ per feeding at 14 days after birth (Table 1), but the symptoms did not improve. Ultimately, the calf died 14 days after birth, at a weight of $9.36 \mathrm{~kg}$. The pathologic autopsy showed that the cause of death was acute pneumonia.

The porpoise colostrum contained $48.7 \%$ water, $30.4 \%$ crude 
Table 1 The 14-day artificial milk regimen.

\begin{tabular}{|c|c|c|c|c|c|c|}
\hline $\begin{array}{l}\text { Age } \\
\text { (day) }\end{array}$ & Formula & $\begin{array}{l}\text { Amount } \\
\text { (/feed })\end{array}$ & $\begin{array}{c}\text { Intake calorie } \\
\text { (kcal/day) }\end{array}$ & $\begin{array}{l}\text { Fat } \\
(\%)\end{array}$ & $\begin{array}{c}\text { Protein } \\
(\%)\end{array}$ & $\begin{array}{c}\text { Carbohydrate } \\
(\%)\end{array}$ \\
\hline 2 & 20\% Esbilac & $40 \mathrm{ml}$ & 345.6 & 8 & 6.6 & 3 \\
\hline \multirow{2}{*}{3} & 20\% Esbilac & $40 \mathrm{ml}$ & \multirow{2}{*}{510.6} & \multirow{2}{*}{11.3} & \multirow{2}{*}{6.1} & \multirow{2}{*}{2.9} \\
\hline & fresh cream & $4 \mathrm{ml}$ & & & & \\
\hline \multirow{3}{*}{4} & 20\% Esbilac & $40 \mathrm{ml}$ & \multirow{3}{*}{818} & \multirow{3}{*}{11.3} & \multirow{3}{*}{7} & \multirow{3}{*}{4.7} \\
\hline & fresh cream & $4 \mathrm{ml}$ & & & & \\
\hline & salmon oil & $2 \mathrm{ml}$ & & & & \\
\hline \multirow{3}{*}{5} & 20\% Esbilac & $40 \mathrm{ml}$ & \multirow{3}{*}{945.6} & \multirow{3}{*}{11.3} & \multirow{3}{*}{7} & \multirow{3}{*}{4.7} \\
\hline & fresh cream & $4 \mathrm{ml}$ & & & & \\
\hline & salmon oil & $2 \mathrm{ml}$ & & & & \\
\hline \multirow{3}{*}{6} & 25\% Esbilac & $40 \mathrm{ml}$ & \multirow{3}{*}{999.6} & \multirow{3}{*}{13.1} & \multirow{3}{*}{8.4} & \multirow{3}{*}{5.3} \\
\hline & fresh cream & $4 \mathrm{ml}$ & & & & \\
\hline & salmon oil & $2 \mathrm{ml}$ & & & & \\
\hline \multirow{3}{*}{7} & 25\% Esbilac & $50 \mathrm{ml}$ & \multirow{3}{*}{1062.4} & \multirow{3}{*}{12.5} & \multirow{3}{*}{8.4} & \multirow{3}{*}{5} \\
\hline & fresh cream & $4 \mathrm{ml}$ & & & & \\
\hline & salmon oil & $2 \mathrm{ml}$ & & & & \\
\hline \multirow{3}{*}{8} & 25\% Esbilac & $50 \mathrm{ml}$ & \multirow{3}{*}{1086} & & & \\
\hline & fresh cream & $4 \mathrm{ml}$ & & 12.5 & 8.4 & 5 \\
\hline & salmon oil & $2 \mathrm{ml}$ & & & & \\
\hline & 25\% Esbilac & $55 \mathrm{ml}$ & & & & \\
\hline 9 & fresh cream & $4 \mathrm{ml}$ & 1099.5 & 12.3 & 8.4 & 5 \\
\hline & salmon oil & $2 \mathrm{ml}$ & & & & \\
\hline & 25\% Esbilac & $59 \mathrm{ml}$ & & & & \\
\hline 10 & fresh cream & $4 \mathrm{ml}$ & 1236.4 & 12.2 & 8.7 & 5.4 \\
\hline & salmon oil & $3 \mathrm{ml}$ & & & & \\
\hline & 25\% Esbilac & $63 \mathrm{ml}$ & & & & \\
\hline 11 & fresh cream & $4 \mathrm{ml}$ & 1550.9 & 12 & 9.1 & 6.4 \\
\hline & salmon oil & $5 \mathrm{ml}$ & & & & \\
\hline & 25\% Esbilac & $63 \mathrm{ml}$ & & & & \\
\hline 12 & fresh cream & $4 \mathrm{ml}$ & 1754.7 & 12 & 9.1 & 6.4 \\
\hline & salmon oil & $5 \mathrm{ml}$ & & & & \\
\hline & 25\% Esbilac & $63 \mathrm{ml}$ & & & & \\
\hline 13 & fresh cream & $4 \mathrm{ml}$ & 1754 & 12.4 & 9.1 & 6.4 \\
\hline & salmon oil & $5 \mathrm{ml}$ & & & & \\
\hline & 25\% Esbilac & $66 \mathrm{ml}$ & & & & \\
\hline 14 & fresh cream & $4 \mathrm{ml}$ & 1137.8 & 12 & 8.4 & 4.7 \\
\hline & salmon oil & $2 \mathrm{ml}$ & & & & \\
\hline
\end{tabular}

Fat, protein, and carbohydrate are expressed on a dry matter basis.

(based on Wakabayashi et al., 2014 [4]) 
Table 2 The analytical methods used in this study are listed with corresponding references.

\begin{tabular}{ll}
\hline \multicolumn{1}{c}{ Components } & \multicolumn{1}{c}{ Methods } \\
\hline Water & Air-oven method, AOAC Official Method 930.15 \\
\hline Crude fat & Acid hydrolysis-diethyl ether extraction method, AOAC Official Method 954.02 \\
\hline Crude protein & Kjeldahl method, AOAC Official Method 991.20 \\
\hline Crude ash & Ashing method, AOAC Official Method 942.05 \\
\hline
\end{tabular}

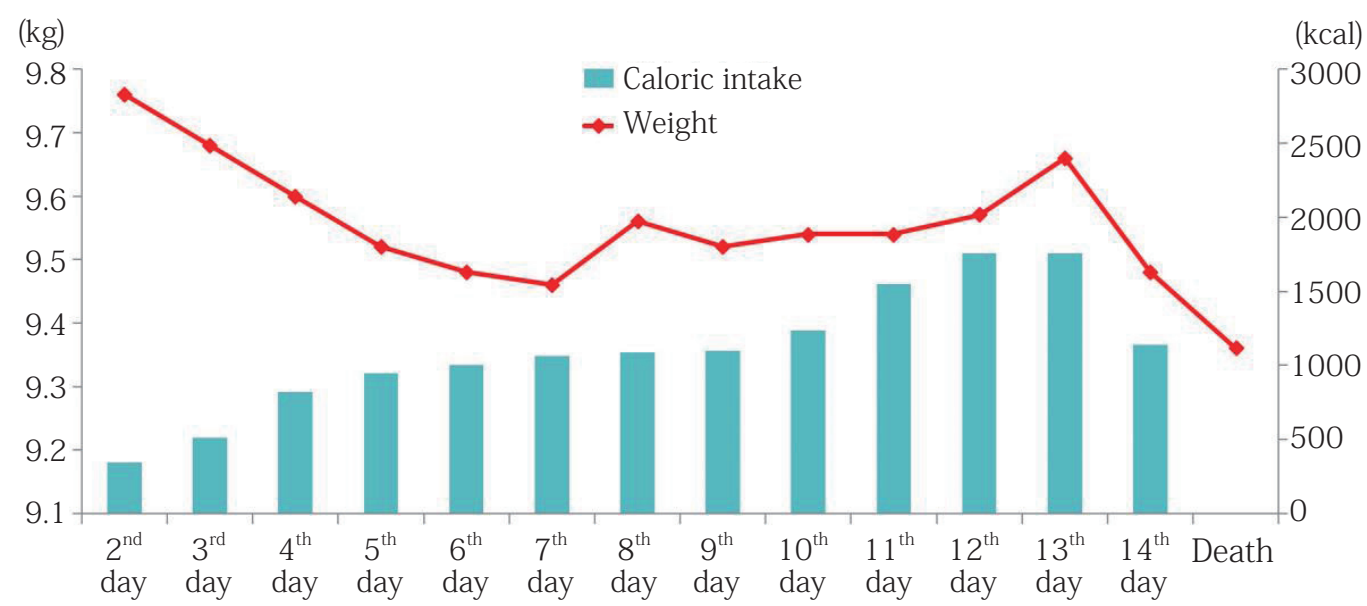

Fig. 3 Changes in body weight and caloric intake of the focal calf.

fat, $20.3 \%$ crude protein, and $0.8 \%$ crude ash. The milk content analysis indicated that harbor porpoise colostrum contained less water and more crude fat and crude protein than that of terrestrial mammals; these characteristics were consistent with the colostrum of other marine mammals [7, 8]. The only previous study of harbor porpoise milk reported $41.1 \%$ water, $45.8 \%$ fat, $11.2 \%$ protein, and $0.57 \%$ ash [18], which constitutes higher fat and lower water, protein, and ash levels than in the present study (Table 3). However, this previous study was conducted more than 130 years ago and included only one sample from an unknown lactation stage. The harbor porpoise colostrum tended to have less water, higher fat (by 0.4-20.2\%), higher protein (by 4.7-11.9\%), and nearly identical ash content compared to other species of odontocetes (Table 3); however, direct comparisons with results from previous studies of other odontocetes should be done with caution, as the sampling periods ranged from early to intermediate stages of lactation (Table 3). Compared to related species, the harbor porpoise colostrum has less water, but higher fat and protein, contents than narrow-ridged finless porpoise (early lactation stage) (Table 3) [4, 16]. Similarly, compared to beluga (unknown lactation stage) which has similar habitat, the harbor porpoise colostrum has less water, but higher fat and protein contents (Table 3) [17].

Marine mammal calves must adapt to lower-temperature marine environments. Therefore, most marine mammals produce milk that is higher in fat and energy than that of the terrestrial mammals to which they are most closely related [8]. The fat content of odontocete milk ranges from 10 to 30\% [7]; however, the crude fat of harbor porpoise milk is relatively high among odontocetes (30.4\% in the present study; $45.8 \%$ reported previously). Harbor porpoises are distributed in cold temperate waters [6]; therefore, their newborns may need to accumulate body fat within a short feeding period via relatively high-fat milk to maintain a constant body temperature. In some pinnipeds and cetaceans, fat levels increase with the stage of lactation. For example, the fat concentration in common bottlenose dolphin milk increases from about $10 \%$ at birth to over 20\% during late lactation [15]; the same pattern has been observed in northern elephant seals (Mirounga angustirostris) 
Table 3 Lactation and milk composition of seven species of odontocetes, and composition of artificial milk powder for marine mammals.

\begin{tabular}{|c|c|c|c|c|c|}
\hline $\begin{array}{l}\text { Species } \\
\text { (Scientific binomial) }\end{array}$ & Duration of gestation & $\begin{array}{c}\text { Duration of } \\
\text { lactation }\end{array}$ & $\begin{array}{l}\text { Age at first } \\
\text { major solids }\end{array}$ & $\mathrm{N}$ & $\begin{array}{l}\text { Lactation stage } \\
\text { (days) }\end{array}$ \\
\hline $\begin{array}{l}\text { Short-beaked common dolphin } \\
\text { (Delphinus delphis) }\end{array}$ & 10-11 months & 16 months & $? ?$ & 1 & Mid \\
\hline $\begin{array}{l}\text { Indian Ocean humpback dolphin } \\
\text { (Sousa plumbea) }\end{array}$ & 10-11 months & $? ?$ & $? ?$ & 1 & Mid \\
\hline $\begin{array}{l}\text { Pantropical spotted dolphin } \\
\text { (Stenella attenuata) }\end{array}$ & $\begin{array}{l}\text { little more than } \\
11 \text { months }\end{array}$ & 20 months & 3-7months & 3 & Mid-late \\
\hline $\begin{array}{l}\text { Common bottlenose dolphin } \\
\text { (Tursiops truncatus) }\end{array}$ & about 12 months & 19 months & $4-11$ months & 17 & $210-360$ \\
\hline $\begin{array}{l}\text { Beluga } \\
\text { (Delphinapterus leucas) }\end{array}$ & 14 months & 20-24 months & 12 months & 1 & $? ?$ \\
\hline \multirow{2}{*}{$\begin{array}{l}\text { Narrow-ridged finless porpoise } \\
\text { (Neophocaena asiaeorientalis) }\end{array}$} & \multirow[b]{2}{*}{$? ?$} & \multirow[b]{2}{*}{$? ?$} & \multirow[b]{2}{*}{ 4-5 months } & $3-5$ & Early \\
\hline & & & & 1 & $\begin{array}{c}\text { Early } \\
\text { (8 days after birth) }\end{array}$ \\
\hline \multirow{2}{*}{$\begin{array}{l}\text { Harbor porpoise } \\
\text { (Phocoena Phocoena) }\end{array}$} & \multirow{2}{*}{ 10-11 months } & \multirow{2}{*}{ 8-12 months } & \multirow{2}{*}{ 2-3 months } & 1 & ?? \\
\hline & & & & 1 & Colostrum \\
\hline Commercially available artificial milk & - & - & - & - & - \\
\hline
\end{tabular}

and Antarctic minke whales (Balaenoptera bonaerensis) $[21,22]$. The crude fat of the harbor porpoise was $30.4 \%$ in colostrum, but the proportion of fat may increase during the intermediate stage of lactation. In addition, the crude protein content of the harbor porpoise colostrum in the present study (20.3\%) was relatively high among odontocetes. The colostrum of ungulates is rich in immunoglobulin, which serves as passive immunity to offspring [14]. In prenatal cetaceans, a previous study has suggested that only a small amount of immunoglobulin is transferred from the epitheliochorial placenta [14]. Although we were unable to analyze a detailed protein profile, the colostrum of the harbor porpoise was rich in protein. Therefore, the immunoglobulins were likely transferred to the calf mainly through the colostrum. In this way, colostrum in harbor porpoises may function to protect calves from surrounding causal agents.

We also compared the results of the present study with the compositions of two types of artificial milk: a keeperformulated milk based on that used at the Toba Aquarium, and the only commercially available milk made specifically for marine mammals (Snow Brand Milk Products Company, td., Tokyo, Japan). The keeper-formulated artificial milk contained
8-13.1\% fat and 6.6-9.1\% protein (Table 1). Thus, the milk was low in fat and protein compared to harbor porpoise colostrum. Furthermore, in the present case, the caloric content of the formula given each day to the calf ranged from 345.6 to $1,754.7 \mathrm{kcal}$ (Table 1, Fig. 3). Previous research has demonstrated that the minimum number of calories necessary to sustain life in the harbor porpoise is $200 \mathrm{kcal} / \mathrm{kg} /$ day [23]. The calf in this study weighed around $9.5 \mathrm{~kg}$; thus, she needed a caloric intake of over 1,900 kcal. Therefore, her body weight likely did not increase due to insufficient calorie intake, especially during the period until 10 days after birth. In this case, the keepers were concerned about diarrhea and reduced the amount of milk, which caused an insufficient caloric intake for the calf. In hindsight, the keepers should have increased the amount of milk supply to provide the required calories while also considering the calf' s physical condition.

The commercial milk contained $15 \%$ fat, $3.76 \%$ protein, $0.7 \%$ ash, and $0.14 \%$ sugar, indicating that it was also low in fat and protein compared to the harbor porpoise colostrum. This artificial milk product should be mixed with supplemental fat and protein before feeding it to the calves of harbor porpoises or other species. Because the milk fat of marine mammals 


\begin{tabular}{cccccccl}
$\begin{array}{c}\text { Water } \\
(\%)\end{array}$ & $\begin{array}{c}\text { Dry matter } \\
(\%)\end{array}$ & $\begin{array}{c}\text { Fat } \\
(\%)\end{array}$ & $\begin{array}{c}\text { Crude protein } \\
(\%)\end{array}$ & $\begin{array}{c}\text { Sugar } \\
(\%)\end{array}$ & $\begin{array}{c}\text { Ash } \\
(\%)\end{array}$ & $\begin{array}{c}\text { Gross energy } \\
(\text { MJ kg-1) }\end{array}$ & \multicolumn{1}{c}{ Location of sampling } \\
\hline 58.6 & 41.4 & 30 & 10.3 & - & 0.8 & 14 & South Africa (Wild) \\
\hline 76.7 & 23.3 & 10.2 & 11.3 & - & 0.8 & 7 & South Africa (Wild) \\
\hline- & - & 22.5 & 8.4 & 1.2 & - & 11 & California (Wild) \\
\hline 73 & 27 & 12.8 & 8.9 & 1 & - & 7 & Hawaii/Bermuda (Captive) \\
\hline $59^{1)}$ & $41^{1)}$ & $26.9^{1)}$ & $10.6^{1)}$ & - & $0.83^{1)}$ & - & Hudson Bay, Canada (Wild) \\
\hline $70.9^{2)}$ & $29.1^{2)}$ & $18.9^{2)}$ & $13.2^{2)}$ & $1.1^{2)}$ & - & - & Yellow/Bohai Sea (Wild) \\
\hline $67.6^{3)}$ & $32.4^{3)}$ & $15.5^{3)}$ & $15.6^{3)}$ & - & $0.7^{3)}$ & - & Japan (Captive) \\
\hline $41.1^{4)}$ & $58.9^{4)}$ & $45.8^{4)}$ & $11.2^{4)}$ & - & $0.57^{4)}$ & - & North Atlantic/Scotland (Wild) \\
\hline $48.7^{5)}$ & $51.3^{5)}$ & $30.4^{5)}$ & $20.3^{5)}$ & - & $0.8^{5)}$ & - & Japan (Captive) \\
\hline $80.4^{6)}$ & $19.6^{6)}$ & $15^{6)}$ & $3.76^{6)}$ & $0.14^{6)}$ & $0.7^{6)}$ & - &
\end{tabular}

Gross composition, duration of gestation, duration of lactation, and age of first major solids originate from Oftedal (2011) [8] except for species annotated with superscripts.

also includes unsaturated fatty acids, fish oil is another recommended addition for artificial marine mammal milk; in contrast, fresh cream should be omitted [13, 24]. At the Toba Aquarium, hand-rearing of narrow-ridged finless porpoises has been successful. In contrast to the calf in the present study, one factor contributing to the success of the Toba Aquarium was that the finless porpoise calf was able to take colostrum for the first 5 days after birth [4]. Based on this information, the hand-rearing of newborns that were unable to take colostrum would be particularly difficult. To successfully hand-rear in a case such as the harbor porpoise at the Otaru Aquarium, a method must be established to provide sufficient calories and immunoglobulins or other immune-function substances to calves, even in cases when animals cannot directly consume the colostrum.

The present study provides valuable information regarding the nutritional composition of harbor porpoise colostrum. However, we still must verify whether the low fat and protein contents of the artificial milk were the cause of the calf' $s$ death at the Otaru Aquarium. The composition of the milk of other marine mammals must be analyzed to formulate appropriate artificial milk products for various species. Whether we will be able to obtain additional harbor porpoise milk samples in the future remains unclear. If so, we must analyze other nutrients as well as important fatty acids and amino acids to produce a more suitable milk supplement for this species. Studying the effect of lactation stage on milk composition would yield even better insight for designing a standard procedure for the entire hand-rearing process, such as that already established for common bottlenose dolphins. Until that time, we have no choice but to develop milk based on the present data as well as on information from other dolphins and marine mammals that feed on similar foods. An artificial milk composition developed based on a detailed analysis of harbor porpoise milk should help to increase the success of hand-rearing.

We would like to express our sincere gratitude to Otaru Aquarium staff members and keepers, Mamoru Kawamoto, Masahiro Nino, and Keisuke Okamoto for their collection of the precious milk sample. This work was supported by the Rakuno Gakuen University project to promote the industrial development of milk (2018).

\section{REFERENCES}

1. World Association of Zoo Aquariums Home Page. Available 
from URL: https://www.waza.org/ (accessed 2020-1-18)

2. Bergfelt DR, Blum JL, Steinetz BG, Steinman KJ, O'Brien JK, Robeck TR. 2017. Relaxin as a hormonal aid to evaluate pregnancy and pregnancy loss in bottlenose dolphins (Tursiops truncatus). Gen Comp Endocrinol 242: 24-29.

3. Adventure World Home Page (https://www.aws-s.com/ topics/detail?id=top1291) (in Japanese, accessed 2020-0317)

4. Wakabayashi I, Seko A, Handa Y, Kasamatsu M. 2014. Reproduction and artificial nursing of finless porpoise at Toba aquarium. Aquabiology 36(1): 36-43.

5. Sweeney JC, Stone R, Campbell M, McBain J, Leger JS, Xitco M, Jensen E, Ridgway S. 2010. Comparative survivability of Tursiops neonates from three US institutions for the decades 1990-1999 and 2000-2009. Aquat Mamm 36: 248-261.

6. Read AJ, Hohn AA. 1995. Life in the fast lane: the life history of harbor porpoises from the Gulf of Maine. Mar Mammal Sci 11: 423-440.

7. Oftedal OT. 1997. Lactation in whales and dolphins: evidence of divergence between baleen-and toothed-species. J Mammary Gland Biol Neoplasia 2: 205-230.

8. Oftedal OT. 2011. Milk of marine mammals. Encyclopedia Dairy Sci 3: 563-580.

9. Blanchet M, Wahlberg M, Ishigami T. 2009. First observation of the parturition and peripartum events in a harbor porpoise (Phocoena phocoena). Aquat Mamm 35: 473-480.

10. Blanchet M, Nance T, Ast C, Wahlberg M, Acquarone M. 2008. First case of a monitored pregnancy of a harbour porpoise (Phocoena phocoena) under human care. Aquat Mamm 34: 9.

11. Otaru aquarium Home Page (https://otaru-aq.jp/) (in Japanese, accessed 2019-12-23)

12. Seiichi K, Norihira M, Mikiko O, Masahiro N, Masatoshi T, Nobuya I. 2018. A case of a monitored pregnancy of Harbour porpoise Phocoena phocoena under human care. $J$ Jpn Assoc Zoo Aqu 60: 33-35.

13. Baumgartner K, Lacave G, Sweeney JC, Will H. 2018. A suggested birth protocol for bottlenose dolphins (Tursiops truncatus)-updated 2015, Zoo Nuremberg. Aquat Mamm 44: 100-109.

14. Langer P. 2009. Differences in the composition of colostrum and milk in eutherians reflect differences in immunoglobulin transfer. J Mammal 90: 332-339.

15. West KL, Oftedal OT, Carpenter JR, Krames BJ, Campbell M, Sweeney JC. 2007. Effect of lactation stage and concurrent pregnancy on milk composition in the dolphin. J Zool 273: 148-160.

16. Zeng X, Huang S, Qian Z, Hao Y, Wang D, Ji J. Nabi G. 2017. Characterization of milk composition in narrow-ridged finless porpoises (Neophocaena asiaeorientalis) at different lactation stages. Mar Mammal Sci 33: 803-816

17. Lauer BH, Baker BE. 1968. Whale milk. I. Fin whale (Balaenoptera physalus) and beluga whale (Delphinapterus leucas) milk: gross composition and fatty acid constitution. Can J Zool 47: 95-97.

18. Purdie P. 1885. Chemical composition of the milk of the porpoise. Chem News J Phys Sci 52: 170.

19. Kawamoto M. 2014. The case of artificial nursing of pinnipeds in Otaru aquarium. Isana 61: 40-43. (in Japanese)

20. Pomeranz Y, Meloan CE. 1987. Food analysis: Theory and practice. 2nd ed., Van Nostrand Reinhold, New York.

21. Riedman M, Ortiz CL. 1979. Changes in milk composition during lactation in the northern elephant seal. Physiol Zool 52: 240-249.

22. Best PB. 1982. Seasonal abundance, feeding, reproduction, age and growth in minke whales off Durban (with incidental observations from the Antarctic). Rep int Whal Commn (special issue 32): 759-786.

23. Reeves RR, Folkens PA. 2002. Sea Mammals of the World, pp. 402-405. A. \& C. Black, London.

24. Kastelein RA, Schooneman NM, Staal C, Boer H. 1997. A method for tube-feeding juvenile harbour porpoises (Phocoena phocoena). In The biology of the harbour porpoise, pp. 63-83. De Spil Publishers, Woerden. 


\title{
育仔放棄されたネズミイルカの初乳の成分分析と人工哺育の試み
}

\author{
松代真琳 ${ }^{1)}$, 角川雅俊 ${ }^{2)}$, 松石 隆 $^{3)}$, 郡山尚紀 ${ }^{1) *}$ \\ 1）酪農学園大学獣医学群獣医保健看護学類動物行動生態研究室 $\overline{0} 069-8501$ 北海道江別市文京台緑町 582 \\ 2）おたる水族館 テ 047-0047 北海道小樽市祝津 3-303 \\ 3) 北海道大学大学院水産科学研究院 $=041-8611$ 北海道函館市港町 3-1-1
}

[2019 年 8 月 1 日受領, 2020 年 4 月 2 日採択 $]$

要 約

本研究では，おたる水族館で育仔放棄されたネズミイルカ幼獣の人工哺育を試みた。生後 14 日で幼獣は死亡したが，母獣から 貴重な初乳を得た。ハクジラ類の中でも本種は授乳期間が短いが, 成分分析の結果, その初乳には粗脂肪と粗蛋白質が豊富に含ま れていた。

キーワード : 初乳, 人工哺育, ネズミイルカ

*責任著者：郡山尚紀（E-mail: kooriyam@rakuno.ac.jp） 